\title{
Hubungan Harga Diri dengan Perilaku Seksual pada Penderita HIV AIDS di Kabupaten Indramayu
}

\author{
Muhammad Saefulloh $^{1}$, Wayunah ${ }^{2}$, Dedeh Husnaniyah ${ }^{3}$ \\ ${ }^{1,2,3}$ Program Studi Ilmu Keperawatan STIKes Indramayu \\ email : 'mumet_plumbon@yahoo.co.id
}

\begin{abstract}
ABSTRAK
Masalah HIV dan AIDS adalah masalah kesehatan masyarakat yang memerlukan perhatian serius. Hal ini karena kasus HIV/AIDS yang dilaporkan setiap tahunnya selalu meningkat secara signifikan. Mayoritas infeksi HIV berasal dari hubungan seksual tanpa pelindung antar individu yang salah satunya terkena HIV. Belum ditemukannya obat untuk mengobati HIV/AIDS menyebabkan orang dengan HIV AIDS (ODHA) akan mengalami perubahanpsikologis, salah satunya adalah harga diri rendah. Hal ini disebabkan karena stigma yang negatif dari masyarakat terhadap ODHA. Respon terhadap harga diri tersebut tidak menutup kemungkinan melakukan upaya untuk menularkan penyakitnya kepada orang lain. Hal ini dapat diwujudkan dengan perilaku seksual yang tidak baik. Desain penelitian adalah deskriptif analitik dengan pendekatan cross sectional. Sampel dalam penelitian ini adalah penderita HIV AIDS yang melakukan pengobatan rutin di unit pelayanan HIV AIDS RSUD Indramayu dan RS Bhayangkara Indramayu. Teknik pengambilan sampel consecutive sample. Jumlah sampel sebanyak 125 orang. Alat pengumpul data berupa quesionare untuk mengukur harga diri dan perilaku seksual. Uji statistik menggunakan uji chi-square. Hasil penelitian didapatkan sebanyak 64 responden memiliki harga diri tinggi $(51,20 \%)$, sebanyak 94 responden memiliki perilaku seksual berisiko $(75,20 \%)$. Hasil uji chi square didapatkan p value 1,00 sehingga dapat disimpulkan tidak ada hubungan antara harga diri dengan perilaku seksual penderita HIV AIDS di Kabupaten Indramayu Tahun 2015 (nilai $\alpha=0,05$; CI 95\%). Perilaku seksual penderita HIV AIDS tidak dipengaruhi oleh harga diri, namun dipengaruhi oleh faktor lain.
\end{abstract}

Kata kunci: harga diri, perilaku seksual, penderita HIV AIDS

\begin{abstract}
The issue of HIV and AIDS is a public health issue that needs serious attention. This is because the reported cases of HIV / AIDS always increase significantly each year. The majority of HIV infections come from unprotected sexual intercourse among individuals one of whom is suffered from HIV. The absence of drugs to treat HIVIAIDS causes HIV AIDS (ODHA) patients experience psychological changes, one of which is low self-esteem. This is due to the negative stigma of the community towards people living with HIV. One of the responses to the self-esteem is try to transmit the disease to others. This can be manifested by bad sexual behavior. The design of the research is analytical descriptive with cross sectional approach. The sample of the study is HIV/AIDS patients who perform routine treatment at HIVIAIDS service unit of RSUD Indramayu and Bhayangkara Indramayu Hospital. technique sampling of the study is Consecutive sample. The samples are 125 people. Data collection instruments are questionare to measure self-esteem and sexual behavior. The chi-square test used to do statistical test. The result of the research shows that 64 respondents have high self esteem (51,20\%), 94 respondents have risky sexual behavior $(75,20 \%)$. Chi square test results $p$ value 1.00 so it can be concluded there is no relation between self-esteem with sexual behavior of HIV AIDS patient in Indramayu Regency Year 2015 (value $\alpha=0,05$; 95\% CI). Sexual behavior of HIV AIDS patient is not influenced by self-esteem, but influenced by other factors.
\end{abstract}

Keywords: self-esteem, sexual behavior, HIV AIDS patient 


\section{PENDAHULUAN}

HIV (Human Immunodeficiency Virus) merupakan virus yang menyerang sistem kekebalan tubuh manusia. Akibat virus ini individu mengalami sindroma yang terjadi akibat menurunnya sistem kekebalan tubuh, yang disebut Accuired Immunodeficiency Syndrome (AIDS) (Gallant, 2010). Penyakit ini akan menimbulkan gangguan sistem tubuh yang terjadi karena menurunnya sistem imum. Gejala tersebut biasanya disebut infeksi oportunistik (Djoerban \& Djauji, 2006; Gallant, 2010).

HIV/AIDS ditularkan melalui cairan tubuh seperti darah. Apabila darah atau cairan tubuh orang yang terinfeksi virus HIV bersentuhan dengan darah, kulit yang terluka, atau membran mukosa orang yang tidak terinfeksi, maka orang tersebut dapat tertular. Penularan melalui jarum suntik dan hubungan seksual tanpa pengaman merupakan dua penyebab utama penularan HIV. Wanita hamil yang terinfeksi HIV juga dapat menularkan pada janin yang dikandungnya selama kehamilan atau saat persalinan dan menyusui (Dillinger, 2007; Smeltzer \& Bare, 2008; Black \& Hawks, 2009).

Masalah HIV AIDS merupakan masalah kesehatan yang perlu mendapatkan perhatian lebih serius karena apabila dilihat dari kasus HIV/AIDS yang dilaporkn setiap tahunnya selalu meningkat secara signifikan. Berdasarkan laporan Komisi Penanggulangan AIDS (KPA) sampai dengan tahun 2012 tercatat 98.390 orang terinfeksi HIV dengan kematian sebanyak 1.146 orang. Sedangkan kasus penularan HIV paling banyak terjadi melalui hubungan seks yang tidak aman sebesar 71,5\% (KPA, 2012).

Orang dengan HIV AIDS (ODHA) akan mengalami berbagai masalah dalam aspek biologis, psikologis, maupun sosial. Banyak penelitian yang mengungkap tentang hubungan kesehatan mental dan HIV/AIDS, dimana terdapat hubungan yang kompleks antara kesehatan mental dan HIV/AIDS (CITIZENLink, 2013). Kesehatan mental didefinisikan sebagai kesejahteraan psikologis dan penyesuaian untuk mencapai tuntutan hidup sehari-hari dengan baik (Stuart, 2006). Masalah kesehatan mental yang ialami oleh penderita HIV/AIDS meliputi depresi, kecemasan, harga diri rendah, skizofrenia, gangguan tidur, gangguan mental organik, serta gangguan mood (AIDS Calgary Awarness Association, 2007; Magdalena, 2007).

Sumber yang mengakibatkan stress pada orang dengan HIV/AIDS adalah tingginya tingkat kematian. ODHA cenderung menilai dirinya negatif dan merasa lebih rendah dari orang lain. Hal ini disebabkan karena adanya stigma yang negatif dari masyarakat terhadap ODHA. Hal ini menyebabkan terjadinya harga diri yang rendah, yang terjadi karena perasaan bersalah, kehilangan citra tubuh yang positif, kehilangan peran, kehilangan pekerjaan, dan kehilangan jaringan sosial (Pramesti, 2016; Sternke, 2010)

Respon terhadap harga diri yang rendah dapat positif maupun negatif. Respon positif dapat diperlihatkan dengan adanya perilaku yang menunjukkan kemajuan, menghargai, dan penerimaan, terutama dalam pencegahan penularan penyakit. Sebaliknya jika koping negatif dapat menimbulkan perasaan depresi, marah, dan dendam sehingga tidak menutup kemungkinan melakukan upaya untuk menularkan penyakitnya kepada orang lain. Hal ini dapat diwujudkan dengan perilaku seksual yang tidak baik.

Studi awal terhadap penderita HIV di Kabupaten Indramayu ditemukan data diantara mereka merasa sudah tidak berharga lagi, sering merasa cemas dengan masa depannya, marah mengapa terinfeksi HIV, serta stigma dan diskriminasi dari lingkungan sekitarnya sehingga cenderung menarik diri. Namun ada beberapa di antara penderita HIV yang tetap dengan gonta ganti pasangan, tidak menggunakan kondom saat berhubungan dengan pasangannya yang tidak terinfeksi HIV.

Berdasarkan latar belakang di atas maka rumusan masalah yang muncul adalah belum 
diketahuinya hubungan antara harga diri dengan perilaku seksual penderita HIV AIDS, sehingga pertanyaan penelitiannya adalah apakah ada hubungan antara harga diri dengan perilaku seksual penderita HIV AIDS di Kabupaten Indramayu?

Penelitian ini bertujuan untuk mengetahui hubungan antara harga diri dengan perilaku seksual penderita HIV AIDS di Kabupaten Indramayu.

\section{METODE}

Desain penelitian ini adalah deskriptif analitik dengan rancangan cross sectional (Sastroasmoro \& Ismael, 2010). Populasi pada penelitian ini adalah penderita HIV AIDS di Wilayah Kabupaten Indramayu. Teknik pengambilan sampel yang akan digunakan adalah consequtive sampling Penelitian dilaksanakan di Wilayah Kabupaten Indramayu, Propinsi Jawa Barat dengan tempat pengambilan data adalah pusat-pusat pelayanan HIV AIDS di Kabupaten Indramayu.

Instrumen yang digunakan merupakan adaptasi dan pengembangan kuesioner harga diri yang berbentuk self assesment yang berisi 15 pernyataan dengan pilihan jawaban Skala Likert $1-4$. Instrumen perilaku seksual berpedoman pada penatalaksanaan penderita HIV AIDS yang diterbitkan oleh Departemen Kesehatan RI. Instrumen berisi 10 pertanyaan dengan pilihan jawaban ya dan tidak.

\section{HASIL}

Penelitian telah dilaksanakan pada bulan Juli Agustus 2015 di Klinik Mawar RSUD Indramayu dan Ruang VCT RS Bhayangkara Indramayu dengan jumlah sampel sebanyak 125 responden.

\section{Karakteristik Responden}

Karakteristik responden yang diteliti meliputi data umur, jenis kelamin, pendidikan, pekerjaan, agama, status perkawainan, sumber informasi, dan faktor resiko. Adapun hasilnya adalah sebagai berikut:

Tabel 1. Distribusi Umur Responden

\begin{tabular}{lcccccc}
\hline Variabel & n & Mean & Median & SD & Min Mak \\
\hline Umur & 125 & 32,32 & 32,00 & 6,53 & 18 & 55 \\
\hline
\end{tabular}

Tabel 2. Karakteristik Responden

\begin{tabular}{|c|c|c|c|}
\hline No & Variabel & Frekuensi & Prosentase \\
\hline \multirow[t]{3}{*}{1.} & Jenis Kelamin & & \\
\hline & a. Laki-laki & 35 & 28,00 \\
\hline & b. Perempuan & 90 & 72,00 \\
\hline \multirow[t]{6}{*}{2.} & Pendidikan & & \\
\hline & a. Tidak sekolah & 5 & 4,00 \\
\hline & b.SD & 68 & 54,40 \\
\hline & c. SMP & 24 & 19,20 \\
\hline & d. SMA & 19 & 15,20 \\
\hline & e.PT & 9 & 7,20 \\
\hline \multirow[t]{7}{*}{3.} & Pekerjaan & & \\
\hline & a. Buruh Kota & 5 & 4,00 \\
\hline & b. Dagang & 24 & 19,20 \\
\hline & c. IRT & 42 & 33,60 \\
\hline & d. Tani/Nelayan & 21 & 16,80 \\
\hline & e. Sopir/Kernet & 3 & 2,40 \\
\hline & f. Wiraswasta & 30 & 24,00 \\
\hline \multirow[t]{5}{*}{4.} & Status Perkawinan & & \\
\hline & a. Belum Menikah & 16 & 12,80 \\
\hline & b. Cerai Hidup & 17 & 13,60 \\
\hline & c. Cerai Mati & 18 & 14,40 \\
\hline & d. Menikah & 74 & 59,20 \\
\hline \multirow[t]{6}{*}{5.} & Sumber Informasi & & \\
\hline & a. Media Massa & 8 & 6,400 \\
\hline & b. Petugas & 115 & 92,00 \\
\hline & Kesehatan & & \\
\hline & c. Teman & 1 & 0,80 \\
\hline & d. Lain-lain & 1 & 0,80 \\
\hline \multirow[t]{11}{*}{6.} & Faktor Resiko & & \\
\hline & a. Heteroseksual & 19 & 15,20 \\
\hline & b. LSL & 8 & 6,40 \\
\hline & c. HRM & 25 & 20,00 \\
\hline & d. Pengguna & 1 & 0,80 \\
\hline & NAPZA & & \\
\hline & e. Pasangan & 11 & 8,80 \\
\hline & Dengan HIV & & \\
\hline & AIDS & & \\
\hline & f. WPS & 59 & 47,20 \\
\hline & g. Waria & 2 & 1,60 \\
\hline
\end{tabular}

Berdasarkan tabel 1 diketahui rata-rata umur responden berumur 32,32 tahun dengan standar deviasi 6,53, umur termuda 18 tahun dan umur tertua 55 tahun. Dapat disimpulkan bahwa usia rata-rata responden berada pada tahap dewasa awal dan merupakan usia produktif. 
Tabel 3. Distribusi Frekwensi Harga Diri Penderita HIV AIDS di Kabupaten Indramayu Tahun 2015

\begin{tabular}{clrc}
\hline No & Harga Diri & Frekuensi & Prosentase \\
\hline 1. & Tinggi & 64 & 51,20 \\
2. & Rendah & 61 & 48,80 \\
\hline & Jumlah & 125 & 100,00 \\
\hline
\end{tabular}

Tabel 4. Distribusi Frekwensi Perilaku Seksual Penderita HIV AIDS di Kabupaten Indramayu Tahun 2015

\begin{tabular}{clcc}
\hline No & Perilaku Seksual & \multicolumn{2}{c}{ Frekuensi Prosentase } \\
\hline 1. & $\begin{array}{l}\text { Tidak Beresiko } \\
\text { (aman) }\end{array}$ & 31 & 24,80 \\
2. & $\begin{array}{l}\text { Beresiko } \\
\text { (tidak aman) }\end{array}$ & 94 & 75,20 \\
\hline \multicolumn{2}{c}{ Jumlah } & 125 & 100,00 \\
\hline
\end{tabular}

Berdasarkan tabel 2 diketahui bahwa berdasarkan jenis kelamin responden terbanyak berjenis kelamin perempuan yaitu 90 responden (72\%), berdasarkan tingkat pendidikan responden terbanyak berpendidikan SD yaitu 68 responden $(54,40)$, berdasarkan pekerjaan responden terbanyak memiliki pekerjaan wiraswasta yaitu 30 responden (24\%), beradasarkan status perkawinan responden terbanyak dengan status menikah yaitu 74 responden $(59,20 \%)$, berdasarkan sumber informasi maka responden terbanyak mendapatkan informasi tentang HIV AIDS dari petugas kesehatan yaitu 115 responden (92\%), dan berdasarkan faktor resiko maka responden terbanyak resiko tertular HIV AIDS sebagai WPS yaitu 59 responden $(47,20 \%)$.

\section{Harga Diri Penderita HIV AIDS di Kabupaten Indramayu}

Jumlah responden pada penelitian ini sebanyak 125 orang. Harga diri dikelompokkan menjadi harga diri tinggi dan harga diri rendah, pengelompokkan didasarkan atas nilai tengah (cut of poin dari skor harga diri seluruh responden). Uraian harga diri penderita HIV AIDS sebagaimana pada tabel 3
Tabel 5. Hasil Uji Statistik Hubungan Harga Diri dengan Perilaku Seksual Penderita HIV AIDS di Kabupaten Indramayu tahun 2015

\begin{tabular}{cccccc}
\hline \multirow{2}{*}{ No } & Harga & \multicolumn{2}{c}{ Perilaku Seksual } & & \\
\cline { 3 - 4 } & Diri & $\begin{array}{c}\text { Tidak Beresiko } \\
(\text { aman) }\end{array}$ & $\begin{array}{c}\text { Beresiko } \\
\text { (tidak aman) }\end{array}$ & & $\begin{array}{c}p \\
\text { value }\end{array}$ \\
\hline 1. & Tinggi & 16 & 48 & 64 & \\
& & $(25,00 \%)$ & $(75,00 \%)$ & $(100 \%)$ & \\
\cline { 1 - 4 } 2. & Rendah & 15 & 46 & 61 & 1,00 \\
& & $(24,60 \%)$ & $(75,40 \%)$ & $(100 \%)$ & \\
\hline & Jumlah & 31 & 94 & 125 & \\
& & $(24,80 \%)$ & $(75,20 \%)$ & $(100 \%)$ & \\
\hline
\end{tabular}

Berdasarkan tabel 3 diketahui berdasarkan harga diri responden maka frekuensi terbanyak adalah harga diri tinggi yaitu 64 responden $(51,20 \%)$. Hasil penelitian dapat disimpulkan bahwa masih banyak responden yang memiliki harga diri tinggi meskipun menderita HIV AIDS.

\section{Perilaku Seksual penderita HIV AIDS di Kabupaten Indramayu}

Jumlah responden pada penelitian ini sebanyak 125 orang. Perilaku seksual dikelompokkan menjadi perilaku seksual tidak beresiko (aman) dan perilaku beresiko (tidak aman) untuk pasangan seksual, pengelompokkan didasarkan atas kategori sesuai skor. Uraian perilaku seksual penderita HIV AIDS sebagaimana pada tabel 4. Berdasarkan tabel 4 diketahui berdasarkan perilaku seksual responden maka frekuensi terbanyak adalah perilaku seksual beresiko yaitu 94 responden $(75,20 \%)$. Hasil penelitian dapat disimpulkan bahwa masih banyak responden yang memiliki perilaku seksual beresiko menularkan HIV AIDS terhadap pasangan seksualnya.

\section{Hubungan Harga Diri dengan Perilaku Seksual Penderita HIV AIDS di Kabupaten Indramayu}

Uji statistik bivariat dilakukan untuk mengetahui hubungan antara harga diri dengan perilaku seksual penderita HIV AIDS. Uji statistik menggunakan chi square dengan nilai $\partial 0,05$. 
Berdasarkan tabel 5 diketahui bahwa dari 64 responden yang memiliki harga diri tinggi sebanyak 16 responden (25\%) yang berperilaku seksual tidak beresiko dan 48 responden $(75 \%)$ yang berperilaku seksual beresiko menularkan HIV AIDS terhadap pasangan seksualnya. Sedangkan dari 61 responden yang memiliki harga diri rendah sebanyak 15 responden $(24,60 \%)$ yang berperilaku seksual tidak beresiko dan 46 responden $(75,40 \%)$ yang berperilaku seksual beresiko menularkan HIV AIDS terhadap pasangan seksualnya. Hasil uji chi square didapatkan $\mathrm{p}$ value 1,00 sehingga dapat disimpulkan tidak ada hubungan antara harga diri dengan perilaku seksual penderita HIV AIDS di Kabupaten Indramayu Tahun 2015 (nilai $\partial 0,05$; CI 95\%)

\section{PEMBAHASAN}

Manusia merupakan mahluk unik yang berbeda satu antara satu dengan yang lainnya termasuk kebutuhan dasarnya. Manusia dalam proses kehidupannya selalu berada pada rentang sehat sakit, dalam suatu waktu tidak selamanya manusia berada pada kondisi sakit dan sebaliknya. Dalam kondisi sakit, manusia akan memiliki keterbatasan dalam pemenuhan biologis, psikologis, dan sosial spiritual (Kozier, et al, 2010)

Responden dalam penelitian ini adalah penderita HIV AIDS. AIDS (Accuired Immune Deficiency Syndrome) merupakan suatu kondisi dimana individu mengalami sindrome akibat penurunan kekebalan tubuh (Black \& Hawk, 2009; Gallant, 2010). AIDS menggambarkan suatu kondisi dimana tubuh telah mengalami infeksi HIV (human immunodeficiency virus) dalam jangka waktu yang cukup lama. Orang dengan HIV AIDS (ODHA) berpotensi sangat besar untuk menularkan HIV pada orang lain. WHO (2007) menjelaskan bahwa HIV ditularkan melalui cairan darah saat tranfusi, perilaku seks yang tidak aman, penggunaan jarum suntik pada penasun, dan jalur parental (ibu hamil kepada anak yang dikandungnya). Pada populasi kunci, penularan HIV terkonsentrasi pada pekerja seks, pelanggan seks, lelaki sesama lelaki (LSL), waria, dan pengguna jarum suntik. Populasi inilah yang sering melakukan perilaku seksual tidak sehat yaitu gonta-ganti pasangan, melakukan anal seks, dan menggunakan jarum suntik secara bersamaan.

Hasil penelitian menunjukkan bahwa sebanyak 94 responden $(75,20 \%)$ responden perilaku seksual yang beresiko (tidak aman). Dikatakan beresiko (tidak aman) karena selama melakukan aktivitas seksual dengan pasanganya menggunakan cara-cara yang dapat menularkan HIV diantaranya gontaganti pasangan, tidak menggunakan kondom, melakukan anal seks, ciuman lidah yang tidak biasa, atau melakukan hubungan seks dengan orang yang beresiko tinggi tertular HIV.

Hasil penelitian ini merupakan hal yang memungkinkan terjadi bila dilihat dari data status perkawinan responden dimana sebanyak 74 orang $(59,20 \%)$ sudah menikah sehingga masih aktif melakukan hubungan seksual dengan pasangannya. Pada orang yang menikah merupakan hal yang wajar melakukan hubungan seks tidak menggunakan pengaman (kondom) karena muncul persepsi di masyarakat bahwa merupakan hal tidak etis bila melakukan hubungan seks dengan suami/istrinya menggunakan kondom meskipun tahu beresiko untuk menularkan HIV pada pasangannya (Benerjee \& Sharma, 2007).

Apabila dilihat dari tingkat pendidikan responden dimana sebanyak 68 orang $(54,40 \%)$ adalah berpendidikan sekolah dasar (SD) sangatlah signifikan, karena orang dengan pendidikan SD akan memiliki kematangan dalam berpikir yang kurang meskipun mungkin informasi tentang perilaku seksual yang aman selalu didapatkan saat kontrol ke unit pelayanan HIV AIDS. Menurut Notoatmojdo (2006), perilaku sesorang didasari oleh pengetahuan individu tersebut, di masyarakat pengetahuan di 
identikkan dengan tingkat pendidikan dimana semakin tinggi tingkat pendidikan maka pengetahuanya akan semakin bagus, begitu pula sebaliknya. Dengan pendidikan, dasardasar pemahaman terhadap suatu masalah merupakan aspek yang krusial dalam proses penyelesaian masalah tersebut.

Halnya dengan HIV AIDS bukanlah merupakan suatu permasalahn yang sederhana untuk dipahami Penanganan HIV AIDS bukan hanya sekedar mengobati penyakit namun menyangkut beberapa aspek terkait termasuk sosial budaya, adat istiadat, keyakinan, dan ekonomi (Benerjee \& Sharma, 2007). Di Indonesia khususnya Kabupaten Indramayu perilaku seksual merupakan hal yang tabu untuk dibicarakan namun disisi lain perilaku seksual menjadi bagian dari kehidupan sosial budaya masyarakat Indramayu, disisi lain pula sosialisasi yang tidak legal menjadi penggerak roda perekonomian masyarakat sekitar. Oleh karena itu penanganan HIV AIDS di masyarakat perlu melibatkan berbagai pihak terkait diantaranya pemerintah daerah, dinas kesehatan, rumah sakit/puskesmas, dinas soaial dan tenaga kerja, departemen agama, kepolisian, dinas pendidikan, dan tokoh masyarakat (Brown, Trujillo, \& Macintyre, 2001)

Berdasarkan variabel harga diri responden, sebanyak 64 orang $(51,20 \%)$ memilki harga diri yang tinggi dalam kehidupannya. Dalam proses kehidupan sehari-hari, harga diri merupakan aspek yang krusial dalam membentuk suatu perilaku. Orang dengan harga diri yang tinggi cenderung bersikap positif terhadap permasalahan yang dihadapinya, sebaliknya orang yang dengan harga diri rendah akan menghadapi suatu maslah secara emosional, tergesa-gesa, dan kadang tidak memikirkan dampak di masa yang datang. (Sternke, 2010).

Pasien HIV AIDS sejak pertama kali datang untuk deteksi dini sudah diberikan konseling (KPA, 2007). Pemberian koseling bertujuan untuk menyiapkan mental dan psikologis pasien sehingga apabila hasil pemeriksaan dinyatakan positif maka pasien sudah siap menerima kenyataan tersebut. Menurut penjelasan perawat penanggung jawab klinik pelayanan HIV AIDS di RSUD Indramayu dan RS Bhayangkara Indramayu, konseling dapat diberikan oleh dokter, perawat, atau psikolog selama kurang lebih 30 menit untuk setiap pasien. Konseling digunakan juga untuk mengantisipasi penurunan mental dan psikologis pasien karena orang dengan menderita HIV AIDS akan memperoleh stigma yang negatif dari masyarakat karena HIV AIDS dianggap penyakit kotor. Penderita HIV AIDS pun harus harus siap mendapat perlakuan diskriminatif dan diasingkan oleh masyarakat.

Kelompok dukungan sebaya (KDS) memiliki peran vital dalam peningkatan harga diri penderita HIV AIDS. Melalui KDS permasalahan-permasalahan yang muncul setelah status ODHA disandang dapat diatasi bahkan dicegah. Melalui KDS para penderita HIV AIDS dapat saling bertukar pengalaman dan dukungan sehingga mereka dapat mengikuti program pengobatan dan perawatan secara rutin dan teratur. Oleh karena itu dukungan psikologis terhadap pasien HIV AIDS perlu terus diberikan sehingga penderita HIV AIDS memiliki status mental dan konsep diri yang sehat .

Hasil uji bivariat menunjukkan bahwa tidak ada hubungan atau pengaruh harga diri terhadap perilaku seksual penderita HIV AIDS di Kabupaten Indramayu ( $\partial \quad 0,05$, CI 95\%). Hasil penelitian ini menunjukkan bahwa perilaku seksual dipengaruhi oleh faktor lain yaitu sosial budaya dan faktor ekonomi. Faktor sosial budaya memiliki peranan penting dalam perilaku seksual karena di kehidupan masyarakat pedesaan terkonsep bahwa suami istri dalam melakukan perilaku seksual khususnya hubungan seks tidak memerlukan batasan yang dapat mengurangi kepuasan lahir dan batin dari masing-masing pasangan. Dari faktor 
ekonomi, masyarakat akan mengabaikan resiko masalah kesehatan yang mungkin muncul daripada mengalami masalah kesulitan ekonomi keluarga, dan hal ini tidak dapat diabaikan ketika pemerintah mengatasi dan mencegah HIV AIDS yang semakin tinggi karena status ekonomi menjadi salah satu pertimbangan derajat atau kedudukan di masyarakat. Oleh karena itu seluruh instansi dan dinas terkait harus sejalan dan saling berkoordinasi dalam mengatasi permasalahan HIV AIDS di Kabupaten Indramayu.

\section{SIMPULAN}

Peneltian ini menyimpulkan bahwa tidak ada hubungan antara harga diri dengan perilaku seksual pada penderita HIV AIDS. Saran yang diberikan adalah konseling untuk penderita HIV AIDS dapat dipertahankan dan ditingkatkan termasuk melibatkan seluruh komponen keluarga. Konseling yang diberikan harus mampu memberikan gambaran yang lebih jelas tentang resiko perilaku seksual yang beresiko atau tidak aman. Pemerintah harus mampu menciptakan lapangan kerja baru bagi penderita HIV AIDS sehingga mereka dapat merubah perilaku seksual tidak sehat tersebut. Pihak dinas pendidikan, departemen agama dan tokoh masyarakat harus lebih diintensifkan dalam mencegah penularan HIV AIDS baik melalui pendidiakan formal maupun informal.

\section{DAFTAR PUSTAKA}

AIDS Calgary Awarness Association. (2007). HIV/AIDS and Mental Health. Briefing Document.

Banerjee, S. \& Sharma, U. (2007). Gender, sexuality, right and HIV: an overvew for community sector organization. ICASO

Black, M.J. \& Hawk, H.J. (2009). Medical surgical nursing: clinical management for positive outcome, Elsevier, Singapura.

Brown, , L., Trujillo, L, \& Macintyre, K. (2001). Intervention to reduce
HIV/AIDS stigma: What have we learned?. UNSAID

CITIZENLink. (2013). Sexual Behavior Associated with HIV-AIDS. Diunduh melalui www.citizenlink.com/ tanggal 16 April 2013.

Dias, S.F., Matos, M.G. and Goncalves, A.C. (2005). Preventing HIV Transmission in Adolescents: an Analysis of portuguese Data From The health Behavior School-Aged Children Study and Focus Group. Eur. J. Public Health. 15(3): 300-304.

Dillinger, M. (2007). Nursing care of patients with HIV Disease and AIDS.

Djoerban, Z. \& Djauzi, S. (2009). HIV/AIDS di Indonesia

Fawole, A.O., Ogunkan, D.V., Adegoke, G.S. (2011). Sexual behavior and perception of HIV/AIDS in Nigerian tertiary institution: university of Ilorin, a case study. Global Journal of Human Social Science. Global Journal Inc. (USA) 11(1)

Gallant, J. (2010). 100 tanya jawab mengenai $H I V$ dan AIDS. Alih bahasa: Alexander Sindoro. Indeks, Jakarta

Komisi Penanggulangan AIDS (KPA). (2012). Situasi HIV dan AIDS di Indonesia

(2007). Strategi Nasional Penanggulangan HIV dan AIDS 2007 2010.

Kozier, B., Erb, G., Berman, A., \& Synder, S.J. (2010). Buku ajar fundamental keperawatan, konsep, proses, dan praktik. (Edisi 7). Jakarta: EGC

Lewis, H. \& Dirksen. (2007). Medical surgical nursing. $7^{\text {th }}$ edition. Missouri Mosby-Year Book Inc, St.Louis

Magdalena (2007). AIDS. Ebers Papyrus. Vol. 3

Pramesti, D. (2016). Harga diri orang dengan HIV

Sastroasmoro, S. \& Ismael, S. I. (2010). dasar-dasar metodologi penelitian klinis. (Edisi 4). Jakarta: Sagung Seto. 
Smeltzer, S.C. \& Bare, G.B. (2008). Brunner \& Suddart's Texbook of Medical surgical. (11 th ed). Philadelphia: Lippincott and Wilkins.

Sternke, J. C. (2010). Self-concept and selfesteem in adolescent with learning diabilities. A research paper Masters of Scient in education Degree in School Psychoology

Stuart, G.W. (2006) Buku saku Keperawatan Jiwa (Edisi 5). Jakarta: EGC
Widodo, A \& Lusida, M.I. (2007). Penyakit infeksi di Indonesia solusi kini \& mendatang. Airlangga University Press, Surabaya:

World Health Organization. (1993). WHO AIDS Surveillance Report. Epidemiology and Surveilance Unit. Geneva.

WHO (2003). Condom Facts and Figures. 